\title{
MODELLING OF CLINKER COOLER AND EVALUATION OF ITS PERFORMANCE IN CLINKER COOLING PROCESS FOR CEMENT PLANTS
}

\author{
J. S. Oyepata ${ }^{1,2,}{ }^{*}$, M. A. Akintunde ${ }^{2}$, O. A. Dahunsi ${ }^{3}$, S. S. Yaru ${ }^{4}$ and E. T. Idowu ${ }^{5}$ \\ 1, 2, 3, 4, 5, Dept. of MeChanical Engr'G, Federal Univ. of TeChnology AKure, Ondo State, Nigeria. \\ 2, BUA CEMENT COMPANY (BUA INTERNATIONAL), OKPELLA, EDO STATE, NIGERIA. \\ Email addresses: ${ }^{1}$ tayo082002@gmail.com, ${ }^{2}$ ajyinka@gmail.com, ${ }^{3}$ tundedahunsi@gmail.com, \\ 4 ssyaru@yahoo.com, 5 eidowu21@yahoo.com
}

\begin{abstract}
Cement manufacturing requires cooling down of hot clinker at temperature of about $1350^{\circ} \mathrm{C}$ to temperature lower than $100^{\circ} \mathrm{C}$ in a cooling system known as clinker cooler. Many plants are unable to cool the clinker below $250^{\circ} \mathrm{C}$. This challenge led to scaling down of actual clinker cooler to a test rig size in the ratio 25:1 suitable for simulation. Computational Fluid Dynamics (CFD) tools (Solid-Works and ANSYS) were used to achieve the simulation. The clinker outlet temperatures obtained from simulations were validated with theoretical evaluation. Results showed that with clinker and cooling air flow rates of $0.2 \mathrm{~kg} / \mathrm{s}$ and $0.54 \mathrm{~kg} / \mathrm{s}$ respectively and with a clinker bed height of $0.6 \mathrm{~m}$. An optimum cooler performance was achieved with clinker outlet temperature of $68^{\circ} \mathrm{C}$. The scaled down cooler was $15 \%$ higher than the existing cooler in terms of recoverable energy and $10 \%$ high in terms of energy efficiency.
\end{abstract}

Keywords: Clinker Cooler, Computational Fluid Dynamics (CFD), Mass flow rate clinker and Mass flow air and Clinker Furnace.

\section{INTRODUCTION}

Clinker cooler is used to reduce the clinker temperature from $1350{ }^{\circ} \mathrm{C}$ in the rotary kiln. This clinker temperature is expected to drop below $100^{\circ}$ $C$ before it can be used at the cement grinding station [1]. The cooling is achieved by passing fresh air through a series of suction fans across the layers of the hot clinkers. The recovered energy (hot air) during this process is used as the main burning air (secondary air) for the rotary kiln and (tertiary air) for kiln with pre-calciner. The remaining air is sent to the stack through the main bag house or electrostatic precipitators (ESP). Once clinker leaves the rotary kiln, it must be cooled rapidly to ensure maximum yield of the alite that contributes to the hardening properties of cement $[2,3]$.

Cement production is energy consuming and capitalintensive energy economics is of particular interest to the investors and stakeholders. Energy recovery has generated interest for more than two decades. Engin and Ari $[3,4]$ studied the energy audit and recovery for a dry type cement rotary kiln system with a capacity of 6000 tons of clinker per day. They showed that $15.6 \%$ of the total energy input could be recovered by optimizing the energy recovery and the clinker cooler efficiency.

Efficiency of a clinker cooler plays a key role in heat recovery from the hot clinkers and subsequent preheating of the air used for calcination. The recovered heat and the preheated air are collectively known as secondary air in the rotary kiln and tertiary air used at the calciner. The unrecovered heat that leaves with the clinker out of the cooler represent the actual heat loss of the system. Reduction of energy consumption in a cement plant requires optimizing operating parameters in the coolers, Worrel et al. [1] and Mundhara [5] explained that improving the efficiency of heat recovery in the clinker cooler would 
lead to fuel saving as well as improving the quality of cement production and reduction of the emission level.

Ahamed et al. [6], reported the first and second law efficiencies of grate cooler using different operating conditions, the energy and exergy recovery efficiencies of the cooling system were found to have increased by $21.5 \%$ and $9.4 \%$ respectively, using energy recovered from the exhaust air.

Due to inadequate heat recuperation or improper cooling of the clinker in the cooler, large volume of water is used in cooling the cement product at cement grinding stations. This cost is enormous in terms of energy loss, equipment and product damage. Figure 1 shows a clinker cooling process inside a clinker cooler. It can be observed from the figure that hot clinker enters the cooler from the left side, which is depicted by a red color. As the clinker moves towards the right side of the cooler on a grate, air is passed into the cooler from four fans positioned at the side of the cooler as seen in the figure. The air from the fans flows across the clinker upwards, thereby cooling down the hot clinker. A change is color of the region is experienced, which is the bluish region seen in the figure, indicating a reduced temperature.

\section{METHODOLOGY}

\subsection{Scaling and Modeling of Clinker Cooler and Heating-Up Furnace (HUF)}

Scaling and modeling of the clinker cooler and heating-up clinker furnace was done with relation to an existing and running plant. The design model was scaled down to a ratio $25: 1$, that is, existing cooler twenty-five (25) and model (Test rig) one (1). The scaling down was based on similitude and dimensional analysis requirements and was used to study the responses of the existing clinker cooler [79].

\subsection{Determination of Heat Transfer across Clinker Cooler Wall}

Clinker cooler is modeled with air-cooling process unit to handle the ambient air before entering insider the clinker cooler, with a series of pan conveyors with a perfect cross-flow heat exchange [10]. The heat transfer and the pressure drop are defined by correlation to macro-hydrodynamic criteria [11]. Figure 2 shows the overview of the modelled clinker cooler and clinker furnace.
The clinker cooler was modelled using equation (1) and (2). The number of hot zones is noted as "Kw" and the number of cold zones is noted as " $L_{c}$ " as shown in Figure 2 [12] as:

and

$$
K_{W}=\frac{H_{W} L_{W} w D_{c l k}}{M_{c l k} t_{\text {res time }}}
$$

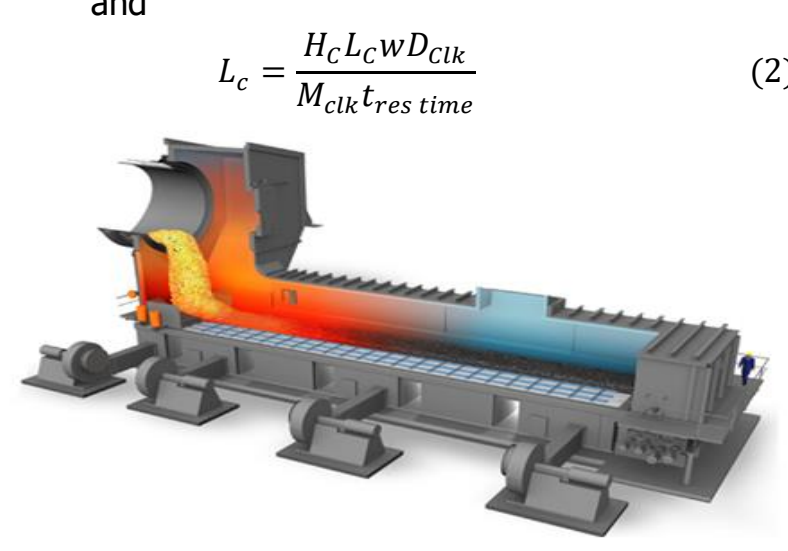

Figure 1: Cross- sectional view of clinker cooling process inside a grate cooler.

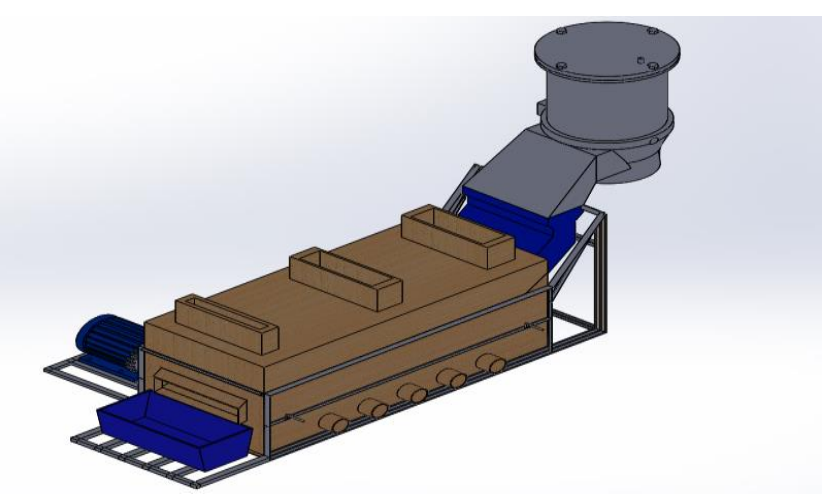

Figure 2: Overview of the conceptualized clinker cooler and clinker furnace

where: $H_{w}$ is the hot zone height, $H_{c}$ is the cold zone height, $D_{C l k}$ is the clinker density,,$H_{c l k}$ is height of clinker bed in hot zone, $L_{w}$ is the length of the clinker in the hot zone, $L_{c}$ is the length of the clinker in the cold zone, $t_{\text {res time }}$ is average resident time. The hot zone height $\left(H_{w}\right)$ of the clinker cooler will be determined using equation (3) [12].

$$
H_{W}=\frac{M_{c l k}}{C_{g} W_{w} D_{c l k} W}
$$

Cold zone height $\left(H_{c}\right)$ of the clinker cooler will be determined using equations (4) [12].

$$
H_{c}=\frac{M_{c l k}}{C_{g} W_{c} D_{c l k} w}
$$

where: $C_{g}$ is the distance covered grate, $w$ is width, $W_{w}$ is the frequency of grate in hot zone, $W_{c}$ is the frequency of grate in cold zone, $M_{c k}$ is the mass flow rate of clinker. Heat losses in each segment depends 
upon heat transfer coefficient, thermal resistance and heat transfer area in each section and these will be determined using equations (5) to (7), [11]:

For heat dissipation losses crossing the wall,

$$
Q_{P i}=\frac{1}{R_{t i}\left(T_{P i}-T_{o}\right)}
$$

For convective heat transfer using the total heat transfer coefficient $h_{f,}$

$$
Q_{P i}=h_{f i} A_{i}\left(T_{i}-T_{p i}\right)
$$

For total thermal resistance $R_{t i}$

$$
R_{t i}=\left(\frac{1}{A_{i}}\left(\frac{t_{b r}}{t_{c r}}+\frac{t_{s}}{t_{c s}}+\frac{1}{h_{c}}\right)\right)
$$

where; $A_{i}$ is segmented area, $Q_{p i}$ is heat loses from each segment, $T_{p i}$ is the wall temperature of each segment, $T_{i}$ is the temperature of each segment, $t_{b r}$ is the thickness of the refractories, $t_{c b r}$ is thermal conductivity, $t_{s}$ is the shell thickness, $t_{c s}$ is thermal conductivity of refractories, $t_{s}$ is the thickness of the shell; and $h_{c}$ is convection heat transfer coefficient. Thermal resistance of any segment depends upon the followings: area, refractories, thermal conductivity of the shell, a shell thickness, and convection heat transfer coefficient $\left(h_{c}\right)$. The convection heat transfer coefficient is obtained using equation. (8) [11]:

$$
h_{c}=\frac{N_{u} K_{\text {air }}}{d_{s}}
$$

Nusselt number $(\mathrm{Nu})$ is obtained using equation (8) [11]:

$$
N_{u}=\left(0.0295\left(\operatorname{Re}^{\frac{4}{5} \operatorname{Pr}^{\frac{1}{3}}}\right)\right)
$$

Reynold number $(\mathrm{Re})$ is also obtained using equation (10)

$$
R e=\frac{d_{s} \rho_{\text {air }} \mu_{\text {air }}}{\left(1-p_{\text {or }}\right) U_{\text {air }}}
$$

Prandtl number $(\mathrm{Pr})$ is determined using equation (11)

$$
\operatorname{Pr}=\frac{\mu_{\text {air }} C \rho_{\text {air }}}{K_{\text {air }}}
$$

where $d_{s}$ is the clinker diameter, $\rho_{\text {air }}$ density of air, $\mu_{\text {air }}$ velocity of air, Por porosity, $K_{\text {air }}$ is the thermal conductivity of air; and $\mu_{\text {air }}$ is the Dynamic viscosity of [11].

\subsection{Performance Evaluation of Mass Flow Rate and Energy Balance Analysis in the Model Clinker Cooler}

Mass flow rate of clinker from kiln exit and cooler exist remain constant as shown in Figure 3 and it is expressed in equation (12):
$M_{\text {Clk in }}+M_{\text {air in }}-M_{\text {air out }}=0$

Therefore, mass flow rate in cooler is constant. For steady state and steady flow process, the mass balance equation as expressed in equation (13) [13]:

$$
\begin{aligned}
& \sum\left(M_{\text {clk }}+M_{\text {air } i n}\right)
\end{aligned}
$$

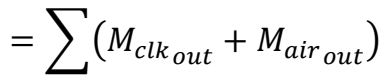

$M$ represents mass flow rate; $c l k$ represents clinker; in represents inlet and Out represents outlet.

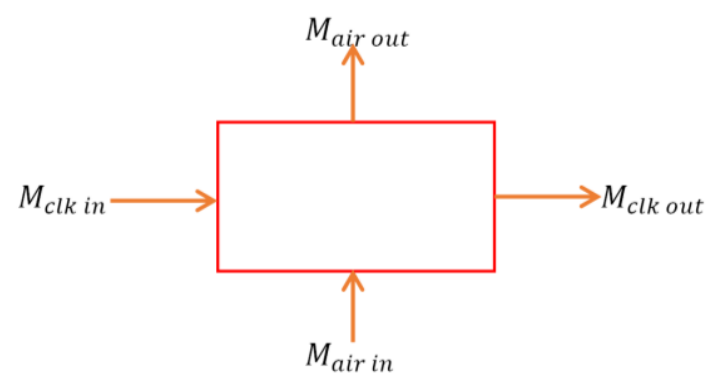

Figure 3 Mass flow rate of cross bar cooler

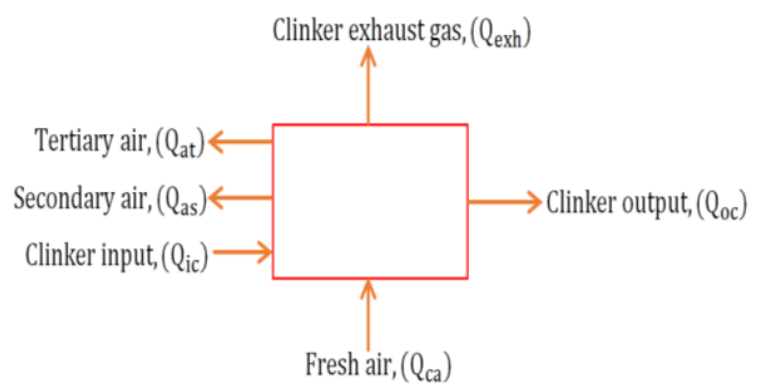

Figure 4 Energy balance schematic of a grate clinker cooler

First law of thermodynamics states that energy can be changed from one form to another during an interaction but cannot be destroyed as shown in Fig. 4. The change in the content of energy of a body or a system is equal to the difference between the energy input and the energy output [14-16]. The energy balance equation $[17,18]$ is as shown in equation (14):

$$
\sum \dot{E_{\text {ln }}}=\sum E_{\text {out }}^{\cdot}
$$

Based on Fig. 4, total input energy can be defined by equation (15)

$$
\begin{aligned}
\sum E_{\text {ln }}=Q_{i c} & +Q_{c a} \\
& =M_{\text {clkin }} c_{p c l k}\left(T_{c l k}-T_{o}\right) \\
& +M_{\text {air }} c_{\text {pair }}\left(T_{a c}-T_{o}\right)
\end{aligned}
$$

Total energy output from the cooler as obtained from [18] can be expressed in equation (16): 


$$
\begin{aligned}
& \sum E_{\text {out }}=Q_{\text {as }}+Q_{a t}+Q_{o c}+Q_{\text {exh }} \\
& =M_{\text {sec air }}\left(T_{\text {sec air }}-T_{\beta}\right) \\
& +M_{\text {ter air }} c_{p \text { air }}\left(T_{\text {ter air }}-T_{\beta}\right) \\
& +M_{\text {clk out }} c_{p \text { clk out }}\left(T_{\text {clk out }}-T_{\beta}\right) \\
& +M_{\text {exh air }} c_{p \text { exh air }}\left(T_{\text {echhair }}\right. \\
& \left.-T_{\beta}\right)
\end{aligned}
$$

$Q_{a s}$ is the recoverable heat rate of kiln secondary air, $Q_{a t}$ is the recoverable heat rate of tertiary air from the cooler, $Q_{o c}$ is the heat of clinker at the cooler output. $Q_{e x h}$ is the heat of cooler at exhaust air, $Q_{i c}$ is the heat of clinker at the cooler input. $Q_{c a}$ is the heat of the cooling air.

Energy efficiency is the ratio of the amount of the energy output to input of the system. It is defined in equation (17) $[14,17]$ :

$$
\eta_{E}=\frac{\sum{\dot{E_{o u t}}}^{\cdot}}{\sum \dot{E_{\text {in }}}}
$$

Equation (18) is recoverable energy efficiency of the secondary and tertiary air as [18]:

$$
\eta_{\text {recoverable, cooler }}=\frac{Q_{\text {recoverable }}}{Q_{i c}+Q_{c a}}
$$

\subsection{Computational Fluid Dynamics (CFD) Simulation}

A 3D model of the clinker bed was developed using SolidWorks2014 CAD software based the geometric parameters adopted in the scaled conceptual design, having fixed values of length, height and width. The model is then imported into ANSYS 14.0 software platform for CFD simulation. Governing equations of flow are solved in the ANSYS-Fluent 14.0 computational fluid dynamics (CFD) platform. Tables 1 and 2 presents the parameters that formed the basis for evaluation of the clinker cooler performance using clinker cooler specific numbers $1.7 \mathrm{Nm}^{3} / \mathrm{kg}$ of clinker and $1.9 \mathrm{Nm}^{3} / \mathrm{kg}$ of clinker.

The clinker is considered and modelled as a porous medium using the facilities available in the software as regard continuity, momentum and energy equations. The 3-D model was meshed in ANSYS meshing environment, where the model was discretized into finite element mesh. The number of elements in a mesh can vary, depending on the level of refinement or size of the cells in the mesh and hence a very fine mesh size was used, taking into consideration computation time and solution accuracy. Boundary conditions were set and the following assumptions considered; porous medium is isotropic and homogenous, flow of fluid is steady, flow is turbulent outside the porous medium and laminar in the porous medium section, fluid is incompressible, radiation heat transfer and heat loss through the wall are negligible.

The clinker bed is a rectangular moving bed with input parameters and dimensions presented in Table 1. Considering the operation of a clinker cooler with respect to the 3-D model used in this study using Fig. 3 , hot clinker enters from the right side; cold air enters from the bottom and moved upward, in form of cross flow. The inlet temperature of the clinker and air were initially set at $1350{ }^{\circ} \mathrm{C}$ and $32{ }^{\circ} \mathrm{C}$ respectively. No slip and adiabatic (no heat loss or heat gain) conditions are assigned to the two sidewalls of the porous medium. Pressure outlet conditions of zero ( 0 ) is assigned to the outlets, so as to determine the pressure drop along the flow, and corresponding temperatures after solution is complete [19].

\subsection{Validation of the numerical simulation}

The procedure involved in the simulation was validated by comparing the result obtained from CFD and theoretical results. Theoretical results are obtained using equation (19) [20].

$$
\frac{T_{c l k_{\text {out }}}-T_{o}}{T_{\text {clk }}-T_{o}}=e^{(- \text {Vair } / 0.77)}
$$

where $T_{c l k_{\text {in }}}$ is clinker temperature at cooler inlet $\left({ }^{\circ} \mathrm{C}\right), T_{\text {clk }}$ out is clinker temperature at cooler outlet $\left({ }^{\circ} \mathrm{C}\right), \quad V_{\text {air }}$ is specific cooling air quantity $\left(\mathrm{m}^{3} / \mathrm{kg}\right)$ in the clinker with the heat content relative to ambient temperature.

Table 1: Parameters and Dimension for Modelled Clinker Cooler

\begin{tabular}{ll}
\hline Description & Value \\
\hline Length of the Cooler & $1.3 \mathrm{~m}$ \\
Width of the Cooler & $0.35 \mathrm{~m}$ \\
Height of the Cooler & $0.2 \mathrm{~m}$ \\
Material Inlet Flow rate to the Cooler & $0.2 \mathrm{~kg} / \mathrm{s}$ \\
Specific Number & $1.9 \mathrm{Nm} / \mathrm{kg}$ of clk \\
Material Inlet Temperature to the Cooler & $1350{ }^{\circ} \mathrm{C}$ \\
Fan energy (MWh/kg clk) & $184 \mathrm{kWh} / \mathrm{kg}$ of \\
Air Inlet flow rate & clinker \\
Ambient air temperature & $0.5 \mathrm{~kg} / \mathrm{s}$ \\
\hline
\end{tabular}




\begin{tabular}{ll}
\multicolumn{2}{c}{ Table 2: Other parameters of existing plant } \\
\hline Description & Value \\
Fan energy & $4.6(\mathrm{MWh} / \mathrm{kg} \mathrm{clk})$ \\
Cooler speed & $16($ stroke/min) \\
Clinker mass flow & $72(\mathrm{~kg} / \mathrm{s})$ \\
Clinker inlet Temp & $1350\left({ }^{\circ} \mathrm{C}\right)$ \\
Clinker Outlet Temp & $250\left({ }^{\circ} \mathrm{C}\right)$ \\
Cooler Length & $30(\mathrm{~m})$ \\
Cooler width & $5(\mathrm{~m})$ \\
Secondary air Temp & $950\left({ }^{\circ} \mathrm{C}\right)$ \\
Specific Number & $1.7\left(\mathrm{Nm}{ }^{3} / \mathrm{kg}\right.$ of clk) \\
Energy Efficiency & $59.2\left({ }^{\circ}\right)$ \\
Recoverable Energy Efficiency & $49.2(\%)$ \\
Exhaust air Temp & $265\left({ }^{\circ} \mathrm{C}\right)$
\end{tabular}

\section{RESULTS AND DISCUSSION}

Figure 5 shows the temperature contour of the modelled clinker bed, the inlet section of the clinker, and the outlet section of clinker. The Figure shows very hot clinker $\left(1350{ }^{\circ} \mathrm{C}\right)$ entering the cooler in a longitudinal direction, and cooling air $\left(32{ }^{\circ} \mathrm{C}\right)$ entering the cooler in the transverse direction. For the temperature values, area weighted average of temperature was computed using the ANSYS solver. The clinker and air inlets were assumed to be continuous hence a dominant color contour was observed for the inlets.

As heat is exchanged between the hot clinker and the cooling air, variation of temperature was observed along the length of the clinker bed. This variation is reasonably represented using the temperature contour legend from coldest at the lower part to hottest at the upper part of the legend. It is very unlikely or impossible to determine the exact temperature value of a specific location on the clinker bed from the contours displayed, hence the area weighted average temperature is computed for a selected face or point.

In this study, the targeted faces are the air inlet, clinker inlet, clinker outlet, secondary air outlet and exhaust air outlet. The area weighted average temperature values for these faces were computed from the solver for three different bed heights; 0.3 $\mathrm{m}, 0.4 \mathrm{~m}$ and $0.6 \mathrm{~m}$. The results are summarized in Table 2. Comparing the CFD results, it was observed that clinker outlet temperature decreased with increase in bed height. This behavior consequently led to increase in secondary air outlet, which is desirable for improving energy recovery. Hence the clinker outlet temperature at bed height of $0.6 \mathrm{~m}$ is said to have the optimal energy recovery into the system, with secondary air at $1017.4^{\circ} \mathrm{C}$ and a low clinker outlet temperature of $68^{\circ} \mathrm{C}$. This implies that bed height plays a significant role in clinker cooler performance.

Evaluating the specific number $\left(\mathrm{Nm}^{3} / \mathrm{kg}\right.$ of clinker): the existing cooler has a specific number as 1.7 $\mathrm{Nm}^{3} / \mathrm{kg}$ of clinker and the modelled clinker was designed to have $1.9 \mathrm{Nm}^{3} / \mathrm{kg}$ of clinker thus the modelled clinker cooler is $12 \%$ higher than the existing clinker cooler. The $12 \%$ increase in specific number of the modelled clinker cooler is also responsible for the decrease in the clinker outlet temperature and also reduction in the exhaust air temperature.

Table 3 and Table 4, are simulation results for Modelling a Clinker Cooler using CFD and Theoretical method to evaluate the clinker cooling process. Energy balance and efficiency of the modelled clinker was also evaluated. Comparing the CFD and the theoretical clinker outlet temperature: CFD clinker outlet temperature at bed height of $0.6 \mathrm{~m}$ has the optimum energy recovery into the system, secondary air at $1017.4{ }^{\circ} \mathrm{C}$ and low outlet clinker temperature with $68{ }^{\circ} \mathrm{C}$. Bed height also plays a significant role in clinker cooler performance. Using Table 2 of the existing cement plant has a clinker outlet temperature which is $250^{\circ} \mathrm{C}$ comparing with CFD results using bed height of $0.6 \mathrm{~mm}\left(68.4{ }^{\circ} \mathrm{C}\right)$ and Theoretical clinker $\left(107{ }^{\circ} \mathrm{C}\right)$ outlet temperature on Table 3 and Table 4.

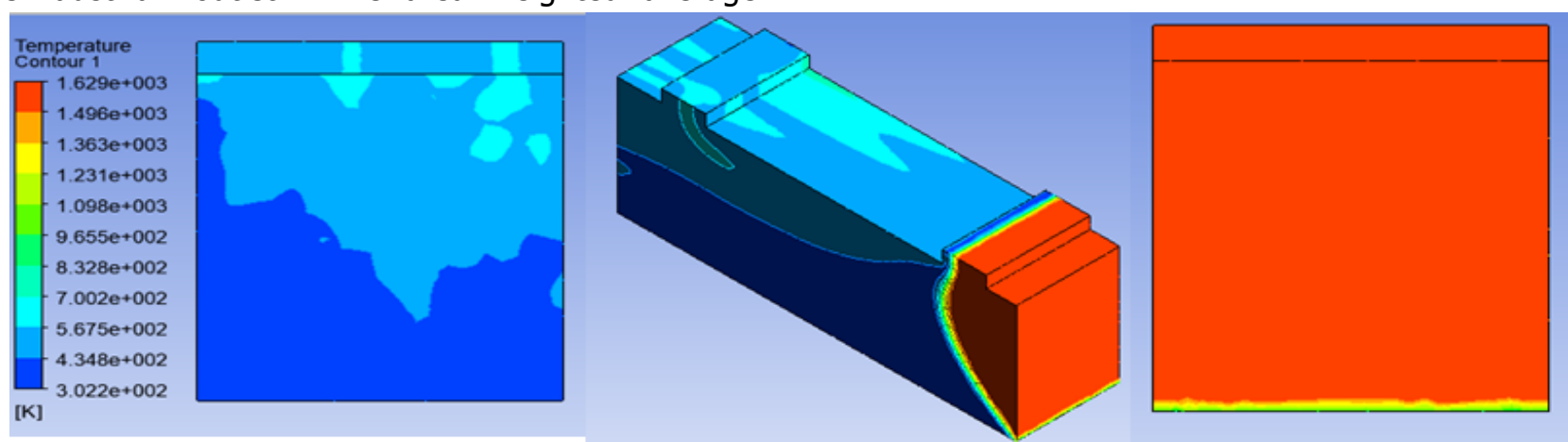

Figure 5: Temperature contour of the clinker cooler outlet end, 3D cross-sectional view and clinker inlet end 
Table 3: Computational Fluid Dynamics Simulation results

\begin{tabular}{lllll}
\hline Description & & Value & & \\
\hline Bed Height $(\mathrm{m})$ & Air inlet & 0.3 & 0.4 & 0.6 \\
& Secondary Air outlet & 32 & 32 & 32 \\
& Exhaust Air outlet & 851.4 & 914.1 & 1017.4 \\
Temperature $\left({ }^{\circ} \mathrm{C}\right)$ & Clinker inlet & 288.3 & 237.5 & 61.1 \\
& Clinker outlet (CFD) & 1350 & 1350 & 1350 \\
& Air inlet & 162.4 & 159.62 & 68.4 \\
& Secondary Air outlet & 0.54 & 0.54 & 0.54 \\
& Exhaust Air outlet & 0.34 & 0.36 & 0.38 \\
Mass Flow rate $(\mathrm{kg} / \mathrm{s})$ & Clinker inlet & 0.20 & 0.18 & 0.16 \\
& Clinker outlet & 0.2 & 0.2 & 0.2 \\
& & 0.2 & 0.2 & 0.2 \\
\hline
\end{tabular}

Table 4: Theoretical and Computational Fluid Dynamics Energy Balance Results

\begin{tabular}{lllll}
\hline & Description & \multicolumn{3}{c}{ Value } \\
\hline Temperature $\left({ }^{\circ} \mathrm{C}\right)$ & Theoretical Clinker outlet & 107.3 & 107.3 & 107.3 \\
& Qic (kcal/kg clk) & 304.5 & 304.5 & 305.4 \\
& Qas (kcal/kg clk) & 198.1 & 198.1 & 198.1 \\
Energy Balance & Qexh (kcal/kg clk) & 210.3 & 252.3 & 324.1 \\
& Qca (kcal//kg clk) & 32 & 24.6 & 11.5 \\
& Qoc (kcal/kg clk) & 21.3 & 21.1 & 14.8 \\
& Losses (kcal/kg clk) & 239.0 & 204.6 & 152.3 \\
& Energy Efficiency (\%) & 52.4 & 59.3 & 70.0 \\
& RecEnergy Efficiency (\%) & 42.4 & 50.2 & 65.0 \\
\hline
\end{tabular}

Existing plant is clinker cooler recoverable energy is $49.2 \%$ and energy efficiency $59.2 \%$ and the modelled clinker cooler recoverable energy and energy efficiency are $65 \%$ and $70 \%$ respectively. The optimum heat of energy recuperation efficiency for the modelled cooler is $70 \%$ and total energy input was into system was $316.0 \mathrm{kcal} / \mathrm{kg}$ of clinker.

The modelled clinker cooler performance when compared with the existing clinker cooler, the modelled cooler is $15 \%$ higher than the existing cooler in terms of recoverable energy and $10 \%$ high in terms of energy efficiency. This large responsible for the high outlet clinker leaving the clinker cooler. However, with proper cooler optimization of the existing cooler the current results obtained from the running can improved upon because poor energy recovery will lead to poor cement qualities, high maintenance cost and low revenue generation.

\section{CONCLUSION}

The study carried out modelling of an actual clinker cooler system with a scaled down test rig prototype in the ratio 25:1. Computational Fluid Dynamics (CFD) simulation was also carried out on the 3D model of the scaled down clinker cooler in order to investigate the performance of the cooler based of variation in geometric parameters. CFD tool was used to create cost-effective simulations of real flows based on numerical solutions of governing equations. The mass flow rate of cold air entering inside the existing clinker cooler and the clinker cooler test rig was designed in a ratio of clinker to cold air which is $1: 2.5 \mathrm{in} \mathrm{kg} / \mathrm{s}$, while clinker bed height investigated are $0.3 \mathrm{~m}, 0.4 \mathrm{~m}$ and $0.6 \mathrm{~m}$. Results from the findings showed that Using these operating parameters for both existing running plant and the scaled down 3D model studied in the CFD tool platform, high outlet clinker temperature is attained with low clinker bed height. This could be because low clinker bed does not allows a proper heat transfer between the bed of clinker and the cold air stream. The modelled clinker cooler performance when compared with the existing clinker cooler is $15 \%$ higher than the existing cooler in terms of recoverable energy and $10 \%$ high in terms of energy efficiency. Additionally, the optimum heat of energy recuperation efficiency for the modelled cooler is $70 \%$ and total energy input was into system was $316.0 \mathrm{kcal} / \mathrm{kg}$ of clinker.

\section{Nomenclature}

\begin{tabular}{lll}
\hline Symbol & Meaning & Unit \\
\hline $\mathrm{Q}_{\mathrm{pi}}$ & Heat losses & $\mathrm{J}$ \\
$\mathrm{R}_{\mathrm{ti}}$ & Total internal resistance & $\Omega$ \\
$\mathrm{T}_{\mathrm{pi}}$ & Wall temperature & ${ }^{\circ} \mathrm{C}$ \\
$\mathrm{H}_{\mathrm{fi}}$ & Total heat transfer coefficient & $\mathrm{W} / \mathrm{mK}$ \\
$\mathrm{A}_{\mathrm{i}}$ & Segmented area & $\mathrm{m}^{2}$ \\
$\mathrm{~T}_{\mathrm{i}}$ & Temperature of each segment & ${ }^{\circ} \mathrm{C}$ \\
$\mathrm{T}_{\mathrm{br}}$ & Thickness of the refractories & $\mathrm{m}$ \\
\hline
\end{tabular}




\begin{tabular}{|c|c|c|}
\hline Symbol & Meaning & Unit \\
\hline$T_{c s}$ & Thermal Conductivity & $\mathrm{W} / \mathrm{mK}$ \\
\hline $\mathrm{T}_{\mathrm{sbr}}$ & Thermal conductivity & $\mathrm{W} / \mathrm{mK}$ \\
\hline $\mathrm{T}_{\mathrm{s}}$ & Shell thickness & ${ }^{\circ} \mathrm{C}$ \\
\hline $\mathrm{H}_{\mathrm{c}}$ & Convection heat transfer coefficient & $\mathrm{W} / \mathrm{m}^{2} \mathrm{k}$ \\
\hline $\mathrm{K}_{\mathrm{w}}$ & Number of hot zone & \\
\hline$L_{c}$ & Number of cold zone & \\
\hline $\mathrm{H}_{\mathrm{w}}$ & Hot zone height & $\mathrm{m}$ \\
\hline $\mathrm{H}_{\mathrm{c}}$ & Cold zone height & $\mathrm{m}$ \\
\hline$D_{c l k}$ & Clinker density & $\mathrm{kg} / \mathrm{m}^{3}$ \\
\hline $\mathrm{H}_{\mathrm{clk}}$ & Height of the clinker bed in hot zone & $\mathrm{m}$ \\
\hline $\mathrm{Lw}_{w}$ & Length of the clinker in the hot zone & $\mathrm{m}$ \\
\hline$L_{c}$ & Length of the clinker in the hot zone & $\mathrm{m}$ \\
\hline Tres time & Average resident time & S \\
\hline $\mathrm{H}_{w}$ & Hot zone height of the cooler & $\mathrm{m}$ \\
\hline $\mathrm{H}_{\mathrm{c}}$ & Cold zone height of the cooler & $\mathrm{m}$ \\
\hline $\mathrm{C}_{\mathrm{g}}$ & Distance covered grate & $\mathrm{m}$ \\
\hline$W_{w}$ & Frequency of grate in hot zone & $\mathrm{Hz}$ \\
\hline$W_{c}$ & Frequency of grate in cold zone & $\mathrm{Hz}$ \\
\hline Mclk & Mass flow rate of Clinker & $\mathrm{kg} / \mathrm{s}$ \\
\hline $\mathrm{H}_{\mathrm{fi}}$ & Heat transfer coefficient & $\mathrm{W} / \mathrm{m}^{2} \mathrm{~K}$ \\
\hline$A_{i}$ & Segmented area & $m^{2}$ \\
\hline$D_{s}$ & Clinker diameter & $\mathrm{m}$ \\
\hline Pair & Density of air & $\mathrm{kg} / \mathrm{m}^{3}$ \\
\hline Uair & Velocity of air & $\mathrm{m} / \mathrm{s}$ \\
\hline Kair & Thermal conductivity of air & $\mathrm{W} / \mathrm{m}^{2} \mathrm{~K}$ \\
\hline 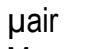 & Dynamic viscosity of air & $\mathrm{Kg} / \mathrm{m} / \mathrm{s}$ \\
\hline M & Mass flow rate & $\mathrm{kg} / \mathrm{s}$ \\
\hline Qas & Recoverable heat of kiln secondary air & $\mathrm{J} / \mathrm{s}$ \\
\hline Qat & Recoverable heat of tertiary air & $\mathrm{J} / \mathrm{s}$ \\
\hline$Q_{o c}$ & Heat of clinker at the cooler output & $\mathrm{J}$ \\
\hline Qexh & Heat of cooler at exhaust air & $\mathrm{J}$ \\
\hline$Q_{\text {ic }}$ & Heat of clinker at the cooler input & $\mathrm{J}$ \\
\hline
\end{tabular}

\section{REFERENCES}

[1] Worrell, E. and Galisky, C. Energy Efficiency, Improvement and Cost Saving Opportunities for Cement Making, An ENERGYSTAR Guide for Energy and Plant Managers. National Laboratory Environmental Energy Technologies Division, Ernest Orlando Lawrence Berkeley National Laboratory, 2008, pp. 3-8.

[2] Punte, S. Holcim Bulacan plant. Use of high efficiency fans and motors for clinker cooler fans, energy efficiency guide for industry in Asia, 2005. Available: http://www.energyefficiencyasia.org.

[3] Oyepata, J. S. Optimizing Cost of Production of Cement with Alternative Fuel Mix. Lambert Academic Publishing, 2018, pp. 9- 25.

[4] Engin, T. and Ari, V. Energy Auditing and Recovery for Dry Type Cement Rotary Kiln Systems. A Case Study. Energy Conversion and Management, 46 (4), pp. 551-562, 2000.

[5] Mundhara, P. and Sharma, S. Modeling of clinker cooler: Applications to reduction in energy consumption. Report: II year Chemical engineering, IIT Madras, 2005, pp. $4-31$.

[6] Ahamed, J. U., Madlool, N. A., Saidur, R., Shahinuddin, M. I., Kamyar, A, and Masjuki, H. H. Assessment of energy and exergy efficiencies of a grate clinker cooling system through the optimization of its operational parameters. Energy, 46 (1), 664 674, 2012.

[7] FLSmidth. ZKG newsletter published by Bauverlag BV $\mathrm{GmbH}$, 7-8, 2015. Aavailable: https://www.zkg.de/imgs/101546732_3bf89cb02a.j pg.

[8] Andreas, S., Benson, S., and Joel, C. Design, Scaling, Similitude and Modeling of Shake-Table Test Structures. Shake Table Training Workshop University of California, San Diego, 2010, CA, pp. 1 52.

[9] Seyyed, K. Engineering Design Process, 2005, pp. 124, www.lisme.org/ETPExemplary.cfm. Accessed on September 24, 2018.

[10] Kunii, D. and Levenspiel, O. Fluidization Engineering ( $2^{\text {nd }}$ edition) Butterworth Heinemann, Lea, F. and Parker, T. (1970). The Chemistry of Cement and Concrete 3rd Ed. Building Research Technical Paper No. 16, 1991.

[11] Raziuddin, A., Tasmeem, A. and Vedika, A. Mass and Energy Balance in Grate Cooler of Cement Plant. International Journal of Scientific Engineering and Technology, 2 (I7), pp. 631-637, 2013.

[12] Touil, D., Belabed, H. and Belaadi, S. Heat Exchange Modeling of Grate Clinker Cooler and Entropy Production Analysis. International Journal of Heat and Technology, 23 (1), pp. 61-68, 2005.

[13] Sögüt, Z., Oktay, Z. and Hepbasli, A. Investigation of Effect of Varying Dead-State Temperature on Energy and Exergy Efficiencies of Raw mill Process in a cement plant. International Journal of Exergy, 6 (5), pp. 655-670, 2009.

[14] Saidur, R., Hasanuzzaman, M., Sattar, M., Masjuki, H., Irfan, M. and Mohiuddin, A. An analysis of energy use, energy intensity and emissions at the industrial sector of Malaysia, International Journal for Mechanical and Material Engineering, 2 (1), pp. 8492, 2007.

[15] Saidur, R., Sattar, M., Masjuki, H., Abdessalam, H. and Shahruan, B. Energy and exergy analysis at the utility and commercial sectors of Malaysia. Energy Policy, 35 (3), pp. 1956-1966, 2007.

[16] Saidur, R., Sattar, M. A., Masjuki, H., Ahmed, S. and Hashim, U. An estimate of the energy and exergy efficiencies for the energy resources consumption in the transportation sector in Malaysia. Energy policy, 35 (8), pp. 4018-26, 2007.

[17] Sögüt, Z., Oktay, Z. and Hepbasli, A. Energetic and Exegetic Assessment of a Trass Mill Process in cement plant. Energy Conversion and Management, 50, pp. 2316-2323, 2009.

[18] Rasul, M., Widianto, W. and Mohanty, B. Assessment of Thermal Performance and Energy Conservation Opportunities of a Cement Industry in Indonesia. Applied Thermal Engineering, 25, pp. 2950-2965, 2005.

[19] ANSYS Release 14.0, ANSYS FLUENT User's Guide ANSYS, Inc.

[20] Holderbank. Cement Seminar. Process Technology, Clinker Coolers, 1 (2), pp. 1 - 41, 2016. 